\title{
PEMBELAJARAN SASTRA BERBASIS KEARIFAN LOKAL PADA SISWA KELAS VIII-1 SMP YP. PANGERAN ANTASARI MEDAN
}

\author{
Pestaria Bakara1, Laura Yohanna Tambunan², Putri Yola Yolanda Panggabean ${ }^{3}$, \\ Lenny Cibro ${ }^{4}$, Relika Sinaga ${ }^{5}$, Syahrizal Akbar ${ }^{6}$ \\ Universitas Prima Indonesia Medan 1,2,3,4,5,6 \\ Posel: pestariabakara@gmail.com
}

\begin{abstract}
The purpose of this study was to find out the effective steps in literary learning based on local wisdom and to find out the process of literary learning based on local wisdom in class VIII-1 of SMP YP. Pangeran Antasari Medan Academic Year 2018/2019. The approach used in this study is a qualitative approach. The results of this study only describe or construct in-depth interviews with the subject of research so that it can provide a clear picture of the understanding of local wisdombased literary learning in class VIII-1 of SMP YP. Pangeran Antasari Medan. This study does not use populations and samples, but uses research subjects. In this study, the data sources were obtained from the determined research sites, namely in class VIII-1 of SMP YP. Antasari Medan. The collection technique in this study consisted of three ways, namely Observation, Interview or interview, and Questionnaire. The results of the study indicate that the learning process and short story learning steps are based on local wisdom in class VIII-1 of SMP YP. Pangeran Antasari Medan is good.
\end{abstract}

Keywords: literary learning; short stories; and local wisdom.

\begin{abstract}
Abstrak
Tujuan penelitian ini ialah untuk mengetahui langkah-langkah yang efektif dalam pembelajaran sastra berbasis kearifan lokal dan untuk mengetahui proses pembelajaran sastra berdasarkan kearifan lokal pada siswa kelas VIII-1 SMP YP. Pangeran Antasari Medan Tahun Pelajaran 2018/2019. Pendekatan yang digunakan dalam penelitian ini adalah pendekatan kualitatif. Hasil dari penelitian ini hanya mendeskripsikan atau mengkonstruksikan wawancara-wawancara mendalam terhadap subjek penelitian sehingga dapat memberikan gambaran yang jelas mengenai pemahaman pembelajaran sastra berbasis kearifan lokal pada siswa kelas VIII-1 SMP YP. Pangeran Antasari Medan. Penelitian ini tidak menggunakan populasi dan sampel, melainkan menggunakan subjek penelitian. Dalam penelitian ini sumber data diperoleh dari tempat penelitian yang sudah ditentukan yakni di kelas VIII-1 SMP YP.Pangeran Antasari Medan. Teknik pengumpulan dalam penelitian ini terdiri atas tiga cara yaitu Observasi, Wawancara atau interview, dan Kuesioner. Hasil penelitian menunjukkan bahwa proses pembelajaran dan langkah-langkah pembelajaran cerpen berbasis kearifan lokal di kelas VIII-1 SMP YP. Pangeran Antasari Medan sudah baik.
\end{abstract}

Kata kunci : pembelajaran sastra; cerpen; dan kearifan lokal.

\section{PENDAHULUAN}

Pewarisan budaya dan nilai kekhasan suatu masyarakat (kearifan lokal) merupakan kekayaan yang harus diwariskan kepada setiap generasi. Budaya, adat istiadat, atau kearifan lokal merupakan salah satu karakteristik sebuah kelompok masyarakat. Pewarisan kearifan lokal tersebut tidak bisa dipisahkan dengan bahasa. Bahasa dominan digunakan sebagai alat penyambung mata rantai antar generasi. Selain dalam bentuk norma baik tertulis atupun tidak, kearifan lokal juga diwujudkan dan dituangkan dalam genre sastra. Sebagaimana yang disampaikan oleh Mustari (Fauzia, 2017) 'Sastra merupakan manifestasi kehidupan masyarakat yang tertuang dalam bentuk karya sastra. Sastra hadir sebagai media pendidikan untuk membangun manusia dan masyarakat yang berkarakter'. 
Karya sastra sebagai suatu media yang terbentuk dari hasil pekerjaan kreatif, objeknya adalah manusia dengan segala persoalan kemanusiaannya (aspek sosial budaya). Seperti yang dikemukakan Damono (Agustina, 2016)'karya sastra selalu menampilkan gambaran kehidupan, sedangkan kehidupan itu sendiri adalah suatu kenyataan sosial. Dengan demikian, segala aspek kehidupan manusia dengan budayanya terdapat dalam sastra, termasuk muatan kearifan lokal yang merupakan pencerminan kebudayaan masyarakatnya'.

Kearifan lokal secara substansial merupakan nilai dan norma yang berlaku dalam suatu masyarakat yang diyakini kebenarannya dan menjadi acuan dalam bertindak dan berperilaku sehari-hari. Dengan kata lain kearifan lokal adalah kemampuan menyikapi dan memberdayakan potensi nilai-nilai luhur budaya setempat. Kearifan lokal merupakan bentuk dialektika antara manusia dengan pengetahuan kehidupan. Pengetahuan yang diambil dari kehidupan dimana manusia itu berada kemudian direfleksikan untuk membantu manusia memaknai kehidupan. Sebagai pedoman masyarakat, selanjutnya kearifan lokal memberi panduan yang jelas ranah-ranah yang dapat dijangkau oleh tingkah laku manusia. Dalam proses terbentuknya, kearifan lokal tidak dikonsepsikan secara individu namun membutuhkan peran komunal yakni masyarakat. Selanjutnya kearifan lokal menjadi bagian dari budaya untuk kemudian menjadi identitas bahkan karakter suatu masyarakat. Karenanya, antara kearifan lokal dan budaya merupakan hubungan antara anak dengan induknya. Kearifan lokal tidak lain adalah bagian dari budaya.

Salah satu bentuk karya sastra yang populer adalah cerpen. Apabila dihubungkan dengan budaya, cerpen mempunyai fungsi sebagai dasar pembentukan nilai-nilai. Pemikiran ini sesuai dengan pendapat Horace (dalam Dawud, dkk., 2016) yang menyatakan bahwa 'sastra memiliki fungsi dulce et utile. Sejalan dengan pendapat Horace, selain mampu menghibur pembaca cerpen juga mengandung amanat yang memunculkan nilai-nilai berisi pesan positif yang dapat dijadikan teladan bagi pembaca'.

Kosasih (2003:222) menyatakan bahwa cerpen adalah cerita yang menurut wujud fisiknya berbentuk pendek. Ukuran panjang pendeknya suatu cerita memang relatif. 'Cerpen merupakan bentuk prosa rekaan yang pendek bukan asal sedikit halaman melainkan masih memersyaratkan adanya keutuhan cerita serta permasalahan yang digarap tidak begitu rumit' Siswantop (dalam I Ketut Ngurah Sulibra, dkk).

Cerpen sebagai salah bentuk karya prosa yang tumbuh dan berkembang di Indonesia memiliki beberapa unsur yang secara umum tidak jauh berbeda dengan karya prosa lainnya (roman dan novel). Unsur tersebut terdiri atas unsur intrinsik dan ekstrinsik.

1) Tema

Tema adalah gagasan atau ide pokok dalam sebuah cerita. Ide tersebut dikembangkan oleh pengarangnya, didalam cerita pengarang memanfaatkan unsur-unsur cerpen. Unsur-unsur tersebutyaitu unsur intrinsik seperti plot, penokohan, serta latar. Didalam tema juga diceritakan tentang persoalan dalam kehidupan manusia seperti masalah kemanusian, kasih sayang, kekuasaan, kecemberuan, dan lain sebagainya. Untuk menetukkan tema kita harus mengenali seperti apa itu unsur intrinsik yang akan digunakan dalam membangun cerita yang ada dalam cerpen tersebut. kita juga perlu mengapreasi karangan-karangan itu tidak hanya sebagian saja tetapi harus secara utuh atau keseluruhan. 
2) Alur

Alur juga biasanya disebut dengan plot. Alur atau plot adalah pola pengembangan cerita yang berhubungan dengan sebab akibat. Dalam alur juga dibahas unsur intrinsik suatu karya sastra pada cerita. Dengan adanya pola pada alur dapat diketahui bagaimana sederhananya jalan cerita pada cerpen .

3) Latar

Latar disebut juga dengan setting. Latar adalah tempat, waktu, dan suasana. Tempat dan waktu yang ada pada cerita bisa merupakan yang sebenarnya bisa juga hanya imajinasi si pengarang.

4) Penokohan

Penokohan merupakan cara pengarang menggambarkan dan mengembangkan karakter tokoh-tokoh dalam cerita. Dalam menggambarkan karakter seorang tokoh pengarang menggunakan teknik analitik dan dramatic.

5) Sudut pandang

Sudut pandang atau point of view adalah posisi pengarang dalam membawakan cerita. Ada dua macam posisi pengarang, yaitu: berperan langsung atau sebagai orang pertama dan hanya sebagai orang ketiga yang berperan sebagai pengamat

6) Amanat

Amanat adalah pesan atau ajaran moral yang harus disampaikan pengarang kepada pembaca melalui karyanya.

7) Gaya bahasa

Gaya bahasa ini berfungsi untuk menciptakan suasana persuasif atau suatu nada serta merumuskan dialog yang mampu memprlihatkan hubungan dan interaksi sesama tokoh.

Selain itu, unsur ekstrinsik pembangun sebuah cerpen sebagai berikut.

1) Latar Belakang Masyarakat

Adanya pengaruh pada latar belakang masyarakat terhadap pembuatan cerpen itu sangat berpengaruh, pemahaman seperti; kondisi politik, ideologi Negara, sosial, dan ekonomi pada masyarakat.

2) Latar Belakang Seorang Pengarang

Adanya pengaruh pada latar belakang seorang pengarang terdiri dari biografi pengarang, kondisi psikologis, aliran sastra yang dimiliki si pengarang terhadap sebuah cerpen.

Nilai kearifan lokal yang terkandung dalam karya sastra sangat penting, terutama dalam mendidik karakter seseorang, sehingga banyak karya sastra yang dimanfaatkan dalam pembelajaran bahasa Indonesia. Adapun Ciri-ciri budaya lokal yang sekaligus berpotensi sebagai kearifan lokal adalah (1) mampu bertahan terhadap budaya luar, (2) memiliki kemampuan mengakomodasi unsur-unsur budaya luar, (3) mempunyai kemampuan mengintegrasikan unsur budaya luar ke dalam budaya asli, (4) mempunyai kemampuan mengendalikan, dan (5) mampu memberi arah pada perkembangan budaya (Ayatrohaedi dalam Dawud, dkk., 2016).

Pembelajaran sastra di SMP bertujuan untuk membangkitkan kreativitas siswa dalam menciptakan dan menilai suatu karya. Selain itu, menurut Rahmanto (Fauziah, 2017) 
pengajaran sastra memiliki 4 manfaat, yaitu: membantu keterampilan berbahasa, meningkatkan pengetahuan budaya, mengembangkan cipta dan rasa, dan menunjang pembentukan watak.

Pembelajaran sastra berbasis kearifan lokal pada saat ini belum diterapkan secara baik, salah satunya pada siswa kelas VIII-1 SMP YP. PANGERAN ANTASARI. Cerpen yang diajarkan kepada siswa di sekolah tidak berkaitan dengan kondisi sosial ataupun adat budaya siswa, kondisi lingkungan siswa, tingkat perkembangan siswa, dan karya sastra yang diajarkan hanya diambil dari buku teks atau buku paket. Hal ini menjadikan pembelajaran sastra cerpen berbasis kearifan lokal kurang diminati oleh siswa-siswi kelas VIII-1 SMP YP. PANGERAN ANTASARI MEDAN. Selama ini, pembelajaran sastra cerpen berbasis kearifan lokal masih kurang dipahami oleh siswa. Salah satu penyebabnya adalah siswa kurang fokus dikarenakan siswa belum sarapan, latar belakang keluarga, dan tidak memperhatikan ketika guru menjelaskan materi pembelajaran.

Berdasarkan latar belakang masalah yang dikemukakan diatas peneliti menggunakan dua cerpen yang berjudul "Lali Panggora" dan "Antara Bali dan Balige" karya Saut Poltak Tambunan,dkk. Dimana cerpen tersebut merupakan contoh cerpen yang berbasis kearifan lokal yang menceritakan kehidupan masyarakat Sumatera Utara.

Ada beberapa tulisan yang relevan dengan penelitian pembelajaran sastra berbasis kearifan lokal, penelitian ini memiliki garis besar fokus yang sama, dan juga memiliki perbedaan, yaitu pada aspek objek kajian. Dalam penelitian relevan ini sebagian mengambil objek kajian novel, sedangkan dalam penelitian ini objek kajian yang dideskripsikan adalah kumpulan cerpen berbasis kearifan lokal.

1. Agustina. 2016. Muatan Kearifan Lokal Dalam Cerpen Mutakhir Karya Cerpenis Minangkabau. Hasil penelitiannya menunjukkan bahwa adanya bentuk kearifan lokal dalam cerpen mutakhir karya cerpenis Minangkabau. Bentuk kearifan lokal itu adalah berdasarkan pandangan hidup (filosofi) berdasarkan kehidupan sosial, nasehat dan iktibar, berdasarkan seremoni atau upacara adat, berdasarkan prinsip, norma dan tata aturan yang terwujud menjadi sistem sosial dan berdasarkan kebiasaan/perilaku seharihari dalam pergaulan sosial.

2. Dawud, dkk. 2016. Kearifan Lokal Dalam Kumpulan Cerpen Siswa Kelas XI SMA N 1 Kepanjen. Hasil penelitiannya menunjukkan tentang norma-norma lokal Jawa seperti laku masyarakat Jawa, pantangan dan kewajiban masyarakat Jawa, ritual dan tradisi masyarakat Jawa, lagu-lagu rakyat Jawa, mios masyarakat Jawa, makanan tradisional Jawa, informasi dan pengetahuan dari sesepu dan pemimpin spritual masyarakat Jawa, cara-cara komunitas masyarakat Jawa dalam memenuhi kehidupannya sehari-hari, alat dan bahan yang dipergunakan untuk kebutuhan tertentu, seni pertunjukan masyarakat jawa, pakaian dan makanan masyarakat Jawa, kondisi sumber daya alam atau kondisi lingkungan yang bisa dim manfaatkan dalam kehidupan masyarakat Jawa sehari-hari, dan permainan tradisional masyarakat Jawa dalam kumpulan cerpen siswa SMAN 1 Kepanjen.

3. Ngurah Sulibra, I Ketut. Revitalisasi Kearifan Lokal Dalam Cerpen Berbahasa Bali : Kajian Sastra Antroplogis. Hasil penelitiannya menunjukkan bahwa cerpen berbasis kearifan lokal di Bali yang muncul tahun 1910-an dan 1920-an mengandung tentang 
pengetahuan-pengetahuan pada masyarakat Bali dan tentang penghormatan/pemujaan terhadap ilmu pengetahuan masyarakat Bali. Dan menceritakan tentang pertentangan batin antara nafsu dan kesetiaan pada masyarakat Bali.

Penelitian ini bertujuan untuk mengajarkan siswa tentang cerpen berbasis kearifan lokal yang terdapat pada daerah masing-masing siswa kelas VIII-1 SMP YP. PANGERAN ANTASARI. Secara khusus, tujuan penelitian ini ialah untuk mengetahui langkah-langkah yang efektif dalam pembelajaran sastra berbasis kearifan lokal pada siswa kelas VIII-1 SMP YP. Pangeran Antasari Medan Tahun Pelajaran 2018/2019 dan untuk mengetahui proses pembelajaran sastra berdasarkan kearifan lokal pada siswa kelas VIII-1 SMP YP. Pangeran Antasari Medan Tahun Pelajaran 2018/2019.

\section{METODE PENELITIAN}

Pendekatan yang digunakan dalam penelitian ini adalah pendekatan kualitatif. Adapun Lokasi Penelitian ialah di Yayasan Pendidikan SMP Pangeran Antasari Medan pada kelas VIII-1 Tahun Pelajaran 2018/2019 Jalan Veteran , Helvetia, Sunggal, Kab. Deli Serdang, Sumatera Utara. Subjek pada penelitian ini adalah guru mata pelejaran Bahasa Indonesia dan siswa kelas VIII-1 SMP YP. Pangeran Antasari, Medan. Adapun yang menjadi objek penelitian ini adalah mengenai pembelajaran sastra berbasis kearifan lokal yaitu cerpen "Antara Bali dan Balige serta Lali Panggora" yang diterapkan pada siswa SMP YP. Pangeran Antasari Medan. Teknik pengumpulan dalam penelitian ini yaitu: observasi, wawancara terstruktur, dokumentasi dan kuesioner tertutup. Teknik analisis pada penelitian ini yang digunakan adalah teknik analisis data deskriptif.

\section{HASIL DAN PEMBAHASAN}

Dari penelitian yang telah dilakukan, maka hasil penelitian dan pembahasannya akan diuraikan dalam bab ini. Hasil penelitian yang akan diuraikan secara garis besar adalah informasi tentang pengetahuan siswa dalam pembelajaran cerpen berbasis kearifan lokal.. Hasil penelitian pembelajaran cerpen berbasis kearifan lokal yang diperoleh adalah kemampuan siswa dalam pengetahuan cerpen ini masih rendah. Dimana siswa kelas VIII-1 masih banyak yang belum mengetahui sastra berbasis kearifan lokal khususnya cerpen. Pembelajaran cerpen berbasis kearifan lokal dilakukan mulai bulan Oktober 2018- April 2019 yang dilaksanakan pada kelas VIII-1 SMP YP.Pangeran Antasari Medan yang berjumlah 37 orang siswa. Dimana dari 37 siswa tersebut, 2 diantaranya tidak dapat hadir. Dan untuk memperoleh data penelitian ini, peneliti memberikan pertanyaan berupa kuesioner sebanyak 10 pertanyaan dengan diikuti 3 pilihan jawaban.

Kajian ini mendeskripsikan analisisnya dengan menginterpre-tasikannya sebagai hasil penelitian.Kajian ini mendeskripsikan data pengetahuan siswa pada pembelajaran cerpen berbasis kearifan lokal dengan memberikan kuesioner pada siswa kelas VIII-1 SMP YP.Pangeran Antasari Medan pada 15 April 2019.

Dapat diketahui persentase pengetahuan pembelajaran sastra berbasis kearifan lokal dengan 10 pertanyaan, dengan rumus jumlah jawaban dibagikan jumlah siswa yang hadir dan dikalikan seratus persen dengan hasil masing-masing tiap pertanyaan yaitu:

$\mathrm{P} 1=\mathrm{A}: 26$ siswa dengan persentase $74,3 \%$ 


\begin{tabular}{|c|c|c|}
\hline \multirow{5}{*}{ P2 } & \multirow{4}{*}{$=$} & B : 1 siswa dengan persentase $2,9 \%$ \\
\hline & & $C: 8$ siswa dengan persentase $22,8 \%$ \\
\hline & & A : 35 siswa dengan persentase $100 \%$ \\
\hline & & B :- \\
\hline & & $C:-$ \\
\hline \multirow[t]{3}{*}{ P3 } & $=$ & A : 21 siswa dengan persentase $60 \%$ \\
\hline & & B : 9 siswa dengan persentase $26 \%$ \\
\hline & & $C: 5$ siswa dengan persentase $14 \%$ \\
\hline \multirow[t]{3}{*}{ P4 } & $=$ & A : 1 siswa dengan persentase $2,9 \%$ \\
\hline & & B : 34 siswa dengan persentase $97,1 \%$ \\
\hline & & $C:-$ \\
\hline \multirow[t]{3}{*}{ P5 } & $=$ & A : - \\
\hline & & B : 33 siswa dengan persentase $94 \%$ \\
\hline & & $C: 2$ siswa dengan persentase $6 \%$ \\
\hline \multirow[t]{3}{*}{ P6 } & $=$ & A : 19 siswa dengan persentase $54 \%$ \\
\hline & & B : 2 siswa dengan persentase $6 \%$ \\
\hline & & $C: 14$ siswa dengan persentase $40 \%$ \\
\hline \multirow[t]{3}{*}{ P7 } & $=$ & A : 31 siswa dengan persentase $88,6 \%$ \\
\hline & & B : 1 siswa dengan persentase $2,9 \%$ \\
\hline & & $C: 3$ siswa dengan persentase $8,5 \%$ \\
\hline \multirow[t]{3}{*}{ P8 } & $=$ & A : 21 siswa dengan persentase $60 \%$ \\
\hline & & B : 4 siswa dengan persentase $11,4 \%$ \\
\hline & & $C: 10$ siswa dengan persentase $28 \%$ \\
\hline \multirow[t]{3}{*}{ P9 } & $=$ & A :- \\
\hline & & B : 35 siswa dengan persentase $100 \%$ \\
\hline & & $C:-$ \\
\hline \multirow[t]{3}{*}{ P10 } & $=$ & A : 11 siswa dengan persentase $31,4 \%$ \\
\hline & & B : 4 siswa dengan persentase $11,4 \%$ \\
\hline & & $C: 20$ siswa dengan persentase $57,2 \%$ \\
\hline
\end{tabular}

\section{Pembelajaran Sastra di SMP Pangeran Antasari Medan}

Pembelajaran sastra di SMP YP. Pangeran Antasari Medan ternyata memiliki objek kajian sastra seperti karya sastra tulis dan lisan. Karya sastra tulis seperti cerita yang sudah ditulis didalam buku, sedangkan karya sastra lisan cerita yang di dapatkan melalui pendengaran seseorang dan disampaikan melalui generasi ke generasi lainnya secara turun temurun. Karya sastra yang di pelajari di Sekolah tersebut ialah cerpen atau cerita pendek.

Pembelajaran sastra lebih diarahkan pada kompetensi siswa dalam memahami dan mengapresiasi sastra. Pembelajaran sastra diajarkan untuk meningkatkan kemampuan siswa dalam menghayati, menikmati, dan memahami karya sastra. Setelah si peneliti melalukan penelitan melalaui wawancara dan data quesioner ternyata guru sudah menjelaskan tentang pembelajaran sastra kearifan lokal kepada mereka. Pembelajaran sastra di SMP YP. Pangeran Antasari Medan kelas VIII-1 hanya mengetahui tentang cerpen saja, tetapi mereka kurang memahami tentang bagaimana cerpen kearifan lokal. Mereka kurang dalam 
mengapresiasi tentang cerpen kearifan lokal. Sedangkan menurut pendapat Tripungkasingtyas, (2016, p. 519) bahwa kegiatan apresiasi itu sebagai wahana yang dapat membina dan mengembangkan kecerdasan emosi siswa perlu di tata secara optimal.

Dalam mempelajari cerpen kearifan lokal ada permasalahan yang di hadapi oleh guru, seperti : (1) guru kurang memahami tentang pengertian kearifan lokal sehingga guru tersebut bingung cara menyampaikan kepada mereka tentang kearifan lokal seperti apa. (2) Guru hanya menjelaskan tentang cerpen dan menyuruh siswa untuk membaca isi dari cerpen tersebut. Guru tidak memberikan contoh bagaimana cerpen kearifan lokal sehingga siswa tidak menguasai materi. (3) Guru tidak pernah mengajak siswa untuk mengikuti lomba karya sastra. Karena itulah pengetahuan siswa mengenai karya sastra mengenai cerpen berbasis kearifan lokal kurang dan mereka juga kurang mampu mengapresiasi unsur pembangun karya sastra yang terdapat dalam cerpen secara baik.

Dalam pengajaran sastra disekolah, bagi mereka pembelajaran karya sastra merupakan pembelajaran yang menyenangkan. Akan tetapi karena masih ada sebagian siswa menganggap sastra sebagai materi yang menjenuhkan, siswa di sekolah menganggap bahwa bahasa indonesia mudah di pelajari sehingga ketika guru memberikan materi tentang cerpen mengenai kearifan lokal untuk mereka tidak perlu di pelajari secara serius. Sehingga dalam mempelajari karya sastra membuat mereka kurang bersemangat dalam belajar.

Dengan demikian dalam pembelajaran sastra guru haruslah lebih selektif dalam memperkenalkan karya sastra berbasis kearifan lokal tersebut. Dengan begitu dalam pembelajaran, guru harus berupaya mengajarkan kepada siswa pembelajaran sastra berbasis kearifan lokal (cerpen) agar siswa mengetahui nila-nilai budaya dan tidak mengabaikan keberadaan nilai-nilai budaya di masa kini. Dengan sastra berbasis kearifan lokal siswa dapat lebih banyak belajar berbudaya dari apa yang seharusnya, terbukanya ruang untuk menggali prinsip dan nilai kebudayaan serta menemukan hal-hal yang bermakna.

\section{Langkah-Langkah Pembelajaran Sastra Berbasis Kearifan Lokal}

Pembelajaran sastra berbasis kearifan lokal penting bagi siswa karena berhubungan dengan keindahan, moral, keagamaan, nilai-nilai budaya, dan khikmad terhadap Tuhan. pembelajaran sastra (cerpen) dimasukkan dalam pendidikan sebagai salah satu upaya untuk melestarikan budaya lokal yang terdapat pada suatu daerah masing-masing siswa. Dalam pembelajaran sastra peneliti berusaha menciptakan strategi pembelajaran berbasis kearifan lokal, supaya siswa mengetahui/mengenali sastra berbasis kearifan lokal khususnya cerpen. Langkah-langkah yang harus dilakukan ialah:

1. Guru melibatkan siswa mengenali cerpen berbasis kearifan lokal dengan mengajak siswa mengamati, membaca, mendengar hal yang penting dari cerpen berbasis kearifan lokal yaitu dua cerpen yang berjudul " Lali Panggora" dan "Antara Bali dan Balige” karya Saut Poltak Tambunan,dkk.

2. Guru melakukan introduksi yaitu memberikan informasi mengenai karya sastra (cerpen) berbasis kearifan lokal yang dibahas seperti uraian singkat, profil penulis, dan konteks kejadian saat karya sastra (cerpen) ditulis.

3. Guru melakukan tahap penyajian dengan menyuruh siswa membacakan karya sastra (cerpen) berbasis kearifan lokal di depan kelas. 
4. Guru menanyakan kepada siswa mengenai apa yang sudah disimak,dibaca, di dengar,dari pembelajaran sastra berbasis kearifan lokal tentang cerpen.

5. Guru mengumpulkan dan mengasosiasikan berbagai kesimpulan dari pembelajaran sastra berbasis kearifan lokal tentang cerpen.

6. Guru menyuruh siswa untuk menceritakan atau mengomunikasikan terhadap apa yang sudah ditemukan dari pembelajaran sastra berbasis kearifan lokal tentang cerpen.

7. Selanjutnya guru menyuruh siswa untuk diskusi, yaitu memberikan kesempatan seluasluasnya kepada siswa untuk memberikan tafsiran.

8. Pada akhirnya pembelajaran ditutup dengan pengukuhan pemahaman karya sastra (cepen) berbasis kearifan lokal yang telah dipelajari.

9. Langkah selanjutnya yaitu evaluasi pembelajaran yang bisa dilakukan dengan memberikan tugas penulisan cerpen berbasis kearifan lokal ke siswa.

Dari hasil observasi, peneliti memperoleh data bahwa guru Bahasa Indonesia di SMP YP. Pangeran Antasari Medan sudah mencamtumkan pembelajaran sastra berbasis kearifan lokal pada siswa kelas VIII-1, walaupun masih ada beberapa siswa yang belum memahami pembelajaran sastra berbasis kearifan lokal.

Setelah melakukan langkah-langkah tersebut, siswa diharapkan mampu memahami cerpen berbasis kearifan lokal yang sesungguhnya. Karena pembelajaran sastra (cerpen) berbasis kearifan lokal sangat penting untuk diketahui para siswa, dan menumbuhkan kesadaran mengenali dan membentuk kembali karakter kebangsaan yang selama ini dilupakan serta mencintai budaya masing-masing siswa khususnya dalam cerita pendek. Dengan demikian pengenalan pembelajaran sastra (cerpen) berbasis kearifan lokal mampu membawa siswa ke kehidupan yang mengenali tentang nilai budaya yang di dapat dari cerpen berbasis kearifan lokal.

\section{Proses Pembelajaran Sastra Berbasis Kearifan Lokal}

Secara umum pada awalnya, proses pembelajaran meminta guru untuk dapat mengetahui bagaimana kemampuan dasar yang dimiliki oleh siswa tentang kemampuan dasarnya, motivasi, latar belakang ekonomi dan akademis serta lainnya. Pada proses ini kesiapan guru harus mampu mengenal karekteristik siswa dalam pembelajaran yang merupakan modal dalam penyampaian bahan ajar serta indikator pelaksanaan pembelajaran.

Proses pembelajaran juga dapat di artikan sebagai kegiatan mengenai penyampaian materi pembelajaran dari guru kepada siswa. Didalam proses pembelajaran adanya guru, siswa, media pembelajaran, materi pembelajaran dan adanya rencana pembelajaran. Pada proses pembelajaran ini guru harus berperan dalam mewujudkan sebuah situasi pembelajaran yang baik bagi para siswa dengan menggunakan rencana pembelajaran yang baik dan sesuai sehingga proses pembelajaran yang diterima oleh siswa dapat di kontrol serta mampu dalam memaksimalkan untuk meningkatkan pemahaman siswa dari materi pembelajaran sastra berbasis kearifan lokal.

Proses pembelajaran adalah proses yang didalanmya terdapat kegiatan interaksi antara guru dengan siswa dan komunikasi timbal balik yang berlangsung dalam situasi edukatif untuk mencapai tujuan belajar Rustaman (dalam bttps://eprints.uny.ac.id. Di undub : 09-Mei2019, 18:22) 
Pengertian proses pembelajaran antara lain menurut Rooijakkers (dalam bttps://eprints.uny.ac.id. Di undub : 09-Mei-2019, 18:22) merupakan suatu kegiatan belajar mengajar menyangkut kegiatan tenaga pendidik, kegiatan peserta didik, pola dan interaksi tenaga pendidik dan peserta didik dan sumber belajar dalam suatu lingkungan belajar dalam kerangka keterlaksanaan program pendidikan.

Sejalan dengan itu, Jogiyanto (dalam bttps://eprints.uny.ac.id. Di unduh : 09-Mei-2019, 18:22) juga berpendapat bahwa pembelajaran dapat didefenisikan sebagai suatu proses yang mana suatu kegiatan berasal atau berubah lewat reaksi suatu situasi yang dihadapi dan karakteristik-karakteristik dari perubahan aktivitas tersebut tidak dapat dijelaskan berdasarkan kecenderungan kecenderungan reaksi asli, kematangan atau perubahanperubahan sementara. Adapun Proses Pembelajaran Sastra Berbasis Kearifan Lokal di Kelas VIII-1 SMP YP. Pangeran Antasari Medan harus di mulai dengan adanya tahap perencanaan, tahap pelaksanaan, tahap evaluasi, yaitu:

a. Tahap perencanaan

Dengan adanya tahap perencanaan Guru menjadi subjek dalam membuat perencanaan pembelajaran dengan menyusun program pengajaran sesuai pendekatan dan metode yang akan digunakan. Pada awalnya Proses pembelajaran sastra berbasis kearifan lokal ialah terlebih dahulu Guru harus mengetahui apa itu pembelajaran sastra berbasis kearifan lokal, kemudian memiliki persiapan tentang apa yang harus di lakukan, serta apa yang harus di pelajari bagaimana menjadi pendidik yang mengetahui bahwa siswa dapat memahami tentang pembelajaran sastra kearifan lokal, dengan cara guru diminta untuk mengetahui kemampuan dasar yang di miliki oleh siswa dari kemampuan dasarnya, motivasinya, minatnya, dan tujuan si siswa guna untuk belajar pembelajaran tersebut.

b. Tahap pelaksanaan

Pada tahap ini, Guru melakukan interaksi belajar mengajar tentang pembelajaran sastra berbasis kearifan lokal dan akan membahas cerpen di sertai dengan adanya metode pembelajaran serta media yang akan digunakan. Dengan adanya metode akan terjadi interaksi antara guru dengan siswa atau siswa dengan lingkungan belajarnya.

Guru juga harus mengenal karakteristik siswa seperti apa, dengan mengetahui karakteristik siswa guru bisa memulai pembelajaran dengan menyampaikan bahan ajar dan menjadi indikator suksesnya pelaksanaan suatu pembelajaran. Ada dua karakteristik dalam pembelajaran yaitu: (a) dalam proses pembelajaran siswa bukan hanya di tuntut untuk mendengar, mencatat, tetapi siswa di minta untuk adanya proses berpikir dari pembelajaran tersebut. (b) kemudian guru membangun suasana pembelajaran dengan cara adanya proses tanya jawab yang di berikan kepada siswa guna untuk memperbaiki dalam meningkatkan kemampuan, serta menggali proses berpikir siswa untuk dapat memperoleh pengetahuan dari apa yang mereka miliki.

Lalu guru harus melaksanakan pembelajaran yang memiliki tujuan secara interaktif, insp ritaif, menyenangkan, menantang, dan memotivasi siswa untuk aktif dalam pembelajaran sastra kearifan lokal. Sehingga siswa dapat memiliki bakat, minat ketika belajar cerpen tentang kearifan lokal. Pertama-tama guru memfasilitasi siswa dengan cara memberikan contoh cerpen tentang kerifan lokal seperti cerpen "Antara Bali Dan Balige Dan Lali Panggoaran" yang berasal dari Sumatera Utara. Agar siswa dapat melakukan pengamatan 
serta memahami dari cerpen tersebut sehingga mereka lebih tertantang untuk lebih mencari tahu cerpen dari daerah meraka masing-masing. Selanjutnya sipeneliti melakukan pengecekan dan memberikan umpan balik serta memberi latihan kepada siswa.

Dengan adanya proses pembelajaran ini guru dapat mendapatkan informasi baru tentang cerpen kearifan lokal yang telah didapatkan dari setiap siswa dan siswa juga mendapatkan tentang bagaimana sebenarnya pembelajaran sastra berbasis kearifan lokal tentang cerpen.

c. Tahap Evaluasi

Pada tahap ini, kegiatan guru ialah melakukan penilaian atas proses pembelajaran yang telah di lakukan pada pembelajaran sastra berbasis kearifan lokal mengenai cerpen. Dengan adanya evaluasi guru dapat mengetahui bagaimana kuntitas dan kualitas pencapaian tujuan pembelajaran yang telah dilaksanakan oleh siswa. Lalu si peneliti menarik kesimpulan dengan cara menanyakan kembali sedikit tentang apa yang sudah di jelaskan dari proses pembelajaran tersebut. Sehingga dengan demikian, dapat disimpulkan bahwa siswa bisa memahami dan mengerti dari pembelajaran sastra berbasis kearifan lokal mengenai cerpen.

\section{SIMPULAN DAN SARAN}

Berdasarkan angket dan observasi yang dilakukan, siswa antusias dan aktif, hanya saja ada beberapa siswa yang kurang paham dalam mengetahui sastra berbasis kearifan lokal. Oleh karena itu peneliti mengenalkan sastra berbasis kearifan lokal berupa cerpen dalam proses pembelajaran, sehingga siswa sudah memahami sastra khususnya cerpen berbasis kearifan lokal dengan baik. Adapun langkah-langkah yang harus dilakukan seorang guru yaitu Guru melibatkan siswa mengenali cerpen berbasis kearifan lokal yang berjudul "Lali Panggora" dan "Antara Bali dan Balige", Guru memberikan informasi mengenai cerpen berbasis kearifan lokal, Guru menyuruh siswa membacakan cerpen berbasis kearifan lokal di depan kelas, Guru menanyakan kepada siswa mengenai apa yang sudah disimak dan dibaca, Guru mengumpulkan berbagai kesimpulan dari pembelajaran sastra berbasis kearifan lokal tentang cerpen, Guru menyuruh siswa untuk menceritakan terhadap apa yang sudah ditemukan dari pembelajaran sastra berbasis kearifan lokal tentang cerpen, Selanjutnya guru menyuruh siswa untuk diskusi, pembelajaran ditutup dengan pengukuhan pemahaman cerpen berbasis kearifan lokal yang telah dipelajari dan langkah selanjutnya yaitu evaluasi pembelajaran yang bisa dilakukan dengan memberikan tugas penulisan cerpen berbasis kearifan lokal ke siswa. Dan dapat disimpulkan bahwa proses pembelajaran dan langkahlangkah pembelajaran cerpen berbasis kearifan lokal di kelas VIII-1 SMP YP. Pangeran Antasari Medan sudah baik.

Berdasarkan uraian termuat dalam simpulan penelitian, ada beberapa saran yang ditujukan kepada siswa dan guru yaitu: saran untuk siswa, mengubah persepsi dan menggali informasi tentang pembelajaran cerpen berbasis kearifan lokal, dan saran untuk guru, yaitu guru diharapkan mampu menciptakan pembelajaran yang menyenangkan terutama pada pembelajaran cerpen berbasis kearifan lokal. 
SeBaSa: Jurnal Pendidikan Bahasa dan Sastra Indonesia

\section{DAFTAR PUSTAKA}

Agustina. 2016. Muatan Kearifan Lokal Dalam Cerpen Mutakbir Karya Cerpenis Minangkabau. Fakultas Bahasa dan Seni Universitas Negeri Padang. Tersedia: http:// ejournal.unp.ac.id/index.php/humanus/index. [01 Maret 2016]

Dawud, dkk. 2016. Kearifan Lokal Dalam Kumpulan Cerpen Siswa Kelas XI SMA N 1 Kepanjen.

Pendidikan Bahasa Indonesia Pascasarjana- Universtas Negeri Malang. Tersedia: http://journal.um.ac.id/index.php/jptpp/artic le/view/6836 [09 September 2016]

Effendi Thahar, Harris. 1998. Kiat Menulis Cerita Pendek. Padang : Pustaka SAI Padang.

Kosasih. 2017. Ketatabahasaan dan Kesusastraan Cermat Berbahasa Indonesia. Bandung : CV.

YRAMA WIDYA Bandung.

Moleong, Lexy. 2012. Metodologi Penelitian Kualitatif. Bandung : PT. Remaja Rosdakarya. Moleong, Lexy. 2017. Metodologi Penelitian Kualitatif. Bandung: PT. Remaja Rosdakarya.

Ngurah Sulibra, I Ketut. Revitalisasi Kearifan Lokal Dalam Cerpen Berbahasa Bali : Kajian Sastra Antroplogis. Program Studi Sastra Bali Universitas Udayana. Tersedia: https://simdos.unud.ac.id/uploads/file_penelitian_1_dir/0b38bad33cfae169b6e9a 022f3d7eb24.pdf.

Nur Praptiwi, Fauzi. 2017. Pendidikan Karakter Tokoh Dalam Novel Cahaya Cinta Pesantren Karangan Ira Madan dan Semester Pertama di Malory Towers Karangan Enid Blyton : SMPIT Tunas Bangsa Insan Mandiri, Depok, Jawa Barat. Pendidikan Bahasa dan Sastra Indonesia. Tersedia: http://doi.org/1021009/AKSIS

Poltak Tambunan, Saut, dkk. 2017. Kolecer \& Hari Raya Hantu. Bandung: Qanita.

Sibarani, Robert. 2012. Kearifan lokal, Hakikat, Peran dan Metode Tradisi Lisan. Jakarta Selatan: Asosiasi Tradisi Lisan.

Sugiyono. 2015. Metode Penelitian Pendidikan (Pendekatan Kuantitatif, Kualitatif, dan R $\mho D)$. Bandung : Alfabeta. 